\title{
Persamaan dan Perbedaan Microsoft Excel 2007, 2010, 2013 dan 2016
}

\author{
Dede Abdullah, Devfy Millenia, Dimita Nusfiana, Ener Ariance, Fransiska Krisnawati, \\ Latufanni Rizqa, Regina Linesiana, Yohanes Zaitun, Khoirul Ngibad* \\ Universitas Maarif Hasyim Latif Sidoarjo \\ *E-mail : khoirul_ngibad@dosen.umaha.ac.id
}

\begin{abstract}
Abstrak
Microsoft Excel adalah sebuah program aplikasi lembar kerja yang merupakan bagian dari paket software Microsoft Office Program ini berfungsi sebagai aplikasi untuk mengolah data secara otomatis yang berupa perhitungan dasar, rumus, pemakaian fungsi maupun table. Pembuatan grafik dan manajemen data juga bisa dikerjakan dengan software ini. Pada tampilan Microsoft excel tahun 2007 fitur-fitur yang digunakan masih terbilang cukup sederhana namun seiring berjalannya waktu maka kebutuhan akan software pengolah data yang lebih canggih memang dibutuhkan. Untuk memenuhi kebutuhan tersebut maka microsoft melakukan improvement dengan meluncurkan software microsoft excel yang lebih canggih dengan fitur-fitur terbaru. Contohnya microsoft excel 2016 yang sudah bisa terhubung dengan berbagai platform yaitu Windows, android, dsb. Tujuan artikel ini adalah untuk mengetahui persamaan dan perbedaan yang ada pada microsoft excel tahun 2007, 2010, 2013 dan 2016. Semoga artikel ini bisa menambah pengetahuan juga bisa bermanfaat bagi para pembaca dan pencari informasi terkait.
\end{abstract}

Keyword : Microsoft excel, persamaan versi microsoft excel, perbedaan versi microsoft excel

\section{Pendahuluan}

Adanya kemajuan teknologi pada saat ini, menyebabkan kebutuhan manusia menjadi terus meningkat dalam berbagai hal. Begitupun dalam bidang teknologi informasi. Adanya teknologi yang semakin hari semakin terus berkembang, saat ini manusia menjadi semakin mudah untuk memenuhi kebutuhannya. Sama halnya dengan program Microsoft Office, program ini banyak membantu para pekerja kantoran, mahasiswa, pelajar dan masih banyak lainnya. Salah satu bagian dari Microsoft Office adalah Microsoft Excel yang juga disebut lembar kerja sebar atau spreadsheets. Di dalam penggunaannya aplikasi ini memiliki fungsi sebagai software untuk kalkulasi dan pembuatan grafik . Dengan strategi pemasaran dari Microsoft yang agresif dan terus berinovasi, menjadikan Microsoft Excel sebagai salah satu program computer yang popular digunakan didalam computer hingga saat ini.

Seiring berjalannya waktu Ms. Excel terus meluncurkan versi-versi terbaru dengan fitur- fitur yang lebih canggih. Namun, Kebanyakan pengguna excel hanya memakainya 
untuk keperluan yang sederhana. padahal penggunaannya masih bisa didalami dengan menggunakan formula dan kombinasi yang mampu mempermudah pekerjaan kita.

\section{Pembahasan}

Microsoft Excel adalah software yang diluncurkan dan dikembangkan oleh Microsoft. Microsoft excel berfungsi untuk pengolahan data yang berupa angka [1]. Software ini sangat identik dengan logo yang khas berwarna hijau. Biasa digunakan untuk mengolah data dalam bentuk angka maupun tabel, juga bisa untuk menyelesaikan pekerjaan statistika karena dilengkapi dengan rumus dan kombinasi formula agar memudahkan pekerjaan kita. Ada berbagai macam tab menu di dalam aplikasi ini, antara lain :

1. Tab home memegang fungsi dasar sebagai pengatur keseluruhan dokumen, di dalam tab home memuat font, paragraph, dll

2. Tab insert adalah tab yang berfungsi untuk memasukkan tabel, gambar, membuat diagram, dll.

3. Tab page layout digunakan untuk mengatur data seperti mengatur ukuran kertas, margin kertas, mengatur tata letak gambar yang disisipkan, dll.

4. Tab formula adalah tab untuk memasukkan rumus-rumus yang ingin digunakan

5. Tab data berfungsi untuk mengatur data misalnya menyaring data, dsb

6. Tab review untuk mengatur ulang atau mengedit data yang sudah dibuat

7. Tab view digunakan untuk melihat tampilan akhir dokumen.

8. Didalam tab masih ada beberapa sub tab dengan masing-masing mempunyai fungsi yang berbeda.

\section{Perbedaan Microsoft excel 2007, 2010, 2013, dan 2016}

\section{Microsoft Excel 2007}

Fitur mudah digunakan oleh para user memiliki eksensi file .xlsx, mendukung format HTML. Ukuran file lebih kecil dibanding versi sebelumnya. Bisa diinstal pada windows XP minimal service pack 2, windows server 2003, vista dan windows server 2008.

\section{Microsoft Excel 2010}

Excel 2010 merupakan versi improved atau lebih sempurna dari versi sebelumnya, beberapa fiturnya yang berbeda yaitu : bentuk tombol office button yang berbeda. Tampilan ribbon lebih simpel dan sederhana. Chart bisa dibuat di satu sel, versi ini diklaim lebih cepat dari versi sebelumnya. Tampilan toolbarnya lebih ringkas. 
Perbedaan pada tampilan ikon dengan versi sebelumnya. Tidak bisa digunakan pada windows vista dan xp. Latar belakang tollbar berwarna putih. Template dimunculkan pada awal lembar kerja baru. Fitur chek out tersedia sebagai jaminan keamanan dokumen. Dokumen dapat dishare, kemudahan dalam pengaplikasian chart dan grafik. Terintegrasi dengan beberapa platform pencarian sehingga bisa menambahkan video atau gambar online dengan bantuan koneksi internet.

Microsoft Excel 2016

Sinkronisasi perangkat lain dengan cara $\log$ in. Share dokumen melalui email atau sosial media. Bermacam-macam pilihan tema dan background. Ikon ribbon dan menu di dalam ribbon dengan tampilan baru. Mendukung tampilan gambar dan data dalam tiga dimensi. Membantu memperkirakan data-data berbasis data historis. Adanya program sertifikasi user Mirosoft Exel dengan dua kategori.

\section{Persamaan Microsoft excel 2007, 2010, 2013, dan 2016}

Adapun persamaan keempat software tersebut adalah persamaan pada jumlah kolom dan baris dan semua versi dilunurkan oleh Mirosoft.

\section{Kesimpulan}

Microsoft Excel adalah salah satu program Microsoft Office yang berguna untuk mengolah data dalam bentuk, angka, tabel maupun statistika. Pengembangan yang dilakukan microsoft menjadikan microsoft excel semakin lama semakin berkembang sesuai dengan kebutuhan manusia di era modern ini. Sehingga software ini masih sangat populer dan digunakan banyak orang.

\section{Daftar Pustaka}

[1] K. Ngibad, "Fungsi Menu-Menu Microsoft Word 2013,” no. 2002, pp. 1-16, 2018. 